DOI: $10.36910 / 6775-2524-0560-2020-39-06$

УДК: 378.147-057.87:005.336.2(477.82)

Клехо Олена Веніамінівна, викладач інформатики

https://orcid.org/0000-0002-2270-0898

Лехіцький Тарас Володимирович, викладач інформатики

Луцький педагогічний коледж, місто Луцьк

\title{
ФОРМУВАННЯ ФАХОВИХ КОМПЕТЕНТНОСТЕЙ СТУДЕНТІВ ПЕДАГОГІЧНОГО КОЛЕДЖУ В УМОВАХ ПРОФЕСІЙНО-ПРАКТИЧНОЇ ПІДГОТОВКИ
}

\begin{abstract}
Клехо О.В., Лехіцький Т.В. Формування фахових компетентностей студентів педагогічного коледжу в умовах професійно-практичної підготовки. У статті розглядається проблема формування фахових компетентностей у студентів педагогічного коледжу під час підготовки та проходження практики. 3'ясовано сучасні підходи до фахової підготовки майбутніх вчителів інформатики для нової української школи, а також висвітлено особливості змісту та методів професійно-практичної підготовки студентів у коледжі. Дослідження базуються на основі викладання фахових дисциплін та проходження різних видів практики для спеціальності «Початкова освіта» $з$ додатковою кваліфікацією вчитель інформатики в початковій школі Луцького педагогічного коледжу. Авторами продемонстровано навчально-методичні матеріали для теоретично-практичної підготовки майбутніх вчителів, а саме, інноваційні технології (мультимедійні, мережеві), технології проблемного та інтерактивного навчання, робимо акцент на тому, що цікаво сучасному студенту, не відмовляючись від традиційної методики. В результаті дослідження обгрунтували окремі аспекти формування фахової компетентності вчителя початкової школи, дослідили і описали структуру та зміст практичної підготовки майбутніх вчителів інформатики у початковій школі. Переконались, що професійно-практична підготовка студентів коледжу - це пріоритетна система освітнього процесу, спрямована на творче застосування знань у процесі реальної педагогічної ситуації.
\end{abstract}

Ключові слова: компетентність, фахова компетентність, компетентнісний підхід, вчитель інформатики в початковій школі, методи та форми навчання.

Клехо Е.В., Лехицкий Т.В. Формирование профессиональных компетенций студентов педагогического колледжа в условиях профессионально-практической подготовки. В статье рассматривается проблема формирования профессиональных компетенций у студентов педагогического колледжа при подготовке и прохождении практики. Выяснено современные подходы к профессиональной подготовке будущих учителей информатики для новой украинской школы, а также освещены особенности содержания и методов профессионально-практической подготовки студентов в колледже.Исследования базируются на основе преподавания профессиональных дисциплин и прохождения различных видов практики для специальности «Начальное образование» с дополнительной квалификацией учитель информатики в начальной школе Луцкого педагогического колледжа.Авторами продемонстрировано учебно-методические материалы для теоретико-практической подготовки будущих учителей, а именно, инновационные технологии (мультимедийные, сетевые), технологии проблемного и интерактивного обучения, делаем акцент на том, что интересно современному студенту, не отказываясь от традиционной методики.В результате исследования обосновали отдельные аспекты формирования профессиональной компетентности учителя начальной школы, исследовали и описали структуру и содержание практической подготовки будущих учителей информатики в начальной школе. Убедились, профессионально-практическая подготовка студентов колледжа - это приоритетная система образовательного процесса, направленная на творческое применение знаний в процессе реальной педагогической ситуации.

Ключевые слова: компетентность, профессиональная компетентность, компетентностный подход, учитель информатики в начальной школе, методы и формы обучения.

Klekho O. , Lekhitskyi T. Formation of professional competences of students of pedagogical college in the conditions of vocational training. The article deals with the problem of formation of professional competences in the students of the pedagogical college during the preparation and passing of the practice. The modern approaches to the professional training of future computer science teachers for the new Ukrainian school are clarified, as well as the peculiarities of the content and methods of professional and practical training of students in college. The research is based on the teaching of professional disciplines and the passage of various types of practice for the specialty "Elementary education" with additional qualification as a teacher of computer science at the elementary school of Lutsk Pedagogical College. The authors demonstrate educational and methodological materials for theoretical and practical training of future teachers, namely, innovative technologies (multimedia, networking), technologies of problem and interactive learning, we emphasize that it is interesting to the modern student, without abandoning the traditional methodology. As a result of the research, some aspects of the formation of professional competence of elementary school teachers were substantiated, the structure and content of practical training of future elementary school teachers were analyzed and described. They were convinced that vocational training of college students is a priority system of the educational process, aimed at creative application of knowledge in the process of real pedagogical situation.

Keywords: competence, professional competence, competence approach, elementary school computer science teacher, teaching methods and forms.

Постановка наукової проблеми. Головною метою підготовки фахівця у соціальноекономічних умовах інформаційного суспільства стає не здобуття ним кваліфікації у вибраній сфері, а набуття та розвиток певних компетентностей, які мають забезпечити йому можливість адаптуватися в умовах динамічного розвитку сучасного світу. 
Проблема формування професійної компетентності майбутнього вчителя початкових класів це підготовка вчителя, здатного глибоко і критично мислити, моделювати освітній процес, самостійно генерувати і втілювати у практику початкової школи нові ідеї та технології навчання $\mathrm{i}$ виховання. Професійно-компетентний вчитель має потенціал як для досягнення вагомих результатів у навчальній діяльності, так і для позитивного впливу на формування цілісної особистості учня, бажання постійно працювати над собою, підвищувати самостійно свій фаховий рівень підготовки [11].

Авторські дослідження будуть базуватися на основі викладання фахових дисциплін та проходження різних видів практики для спеціальності «Початкова освіта» 3 додатковою кваліфікацією вчитель інформатики в початковій школі Луцького педагогічного коледжу, і $\epsilon$ продовженням публікації результатів досліджуваної проблеми.

Аналіз останніх публікацій і досліджень. Закон України «Про освіту» [1], Національна доктрина розвитку освіти [2] пропагують особистісний розвиток вчителя як найвищу цінність суспільства. Цьому присвячені наукові дослідження у галузі філософії освіти (В.Андрущенко, Б.Гершунський, І.Зязюн, В. Кремень та ін.); професійної підготовки фахівців у вищій школі (А. Алексюк, С. Гамараш, С. Гончаренко, А. Гуржій, А. Капська, В. Козаков, М. Лазарєв, П.Підкасистий, В.Семиченко, С.Сисоєва, А.В.Сохань [8] та ін.); теорії компетентнісного підходу до навчання (В. Байденко, Є. Зеєр, I. Зимня, І. Зязюн, Н. Кузьміна) [5 ].

Постановка завдання. Метою статті $є$ продовження теоретичного-практичного обгрунтування окремих аспектів формування фахової компетентності майбутнього вчителя початкової школи та вчителя інформатики в початковій школі, а також висвітлення структури та змісту практичної підготовки майбутніх вчителів інформатики у початковій школі, які успішно реалізовують суть компетентнісного підходу на заняттях 3 методики навчання інформатики у коледжі. А також розробка і демонстрація навчально-методичних матеріалів для підготовки професійно компетентного випускника, педагога.

Виклад основного матеріалу й обгрунтування отриманих результатів досліджень. Давня мудрість говорить: хто стоїть на місці, той відстає, а хто не хоче відставати, мусить рухатися вперед, $\mathrm{i}$ не зупинятися, досягнувши вершини, і підійматися вище. У цьому й полягає основна місія сучасного учителя. Вже не достатньо бути на уроці та поза ним актором, режисером, діловодом, диригентом, дипломатом, психологом, новатором i компетентним фахівцем. Модель сучасного вчителя передбачає готовність до застосування нових освітянських ідей, здатність постійно навчатися, бути у постійному творчому пошуку. Ці якості не видаються з додатком до диплома про педагогічну освіту, а формуються у щоденній учительській праці.

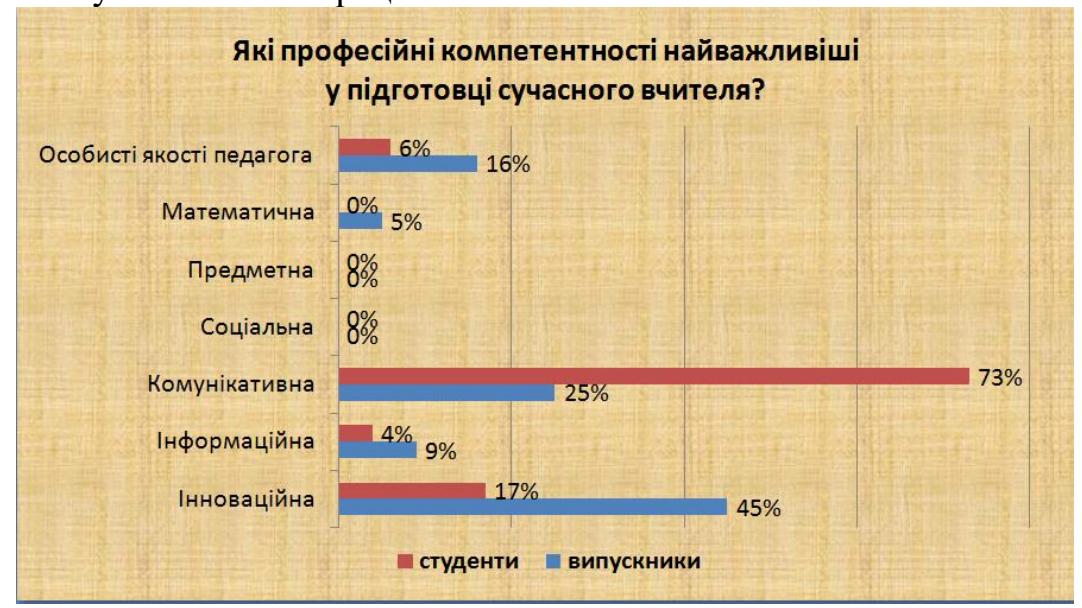

Рис.1. Результати опитування студентів.

Досліджуючи питання професійної компетентності, ми провели опитування студентів, і отримали результати, які змусили нас попрацювати над питанням формування фахової компетентності.

Освітній простір XXI століття визначає компетентнісна освіта. У зв'язку з цим сьогодні головним виміром якості функціонування освітньої системи має бути здатність молодого покоління повноцінно жити і активно діяти в новому світі, постійно самовдосконалюватись, адекватно реагувати на зміни, особливо у періоди технологічних та цивілізаційних змін.

Тобто, щоб прийняти історичний виклад XXI століття, освіта має носити випереджувальний характер, бути націленою в майбутнє, на розв'язання проблем нового століття, розвиток 
компетентності учнів, формування у них проективної культури, нових способів мислення i діяльності. На сучасному етапі в Україні компетентнісний підхід визнано одним із напрямків модернізації освіти. Готовність українських педагогів запровадити компетентнісний підхід у системі освіти задекларовано в основних освітніх документах. Так, у Концепції загальної середньої освіти формування основних компетентностей особистості - життєвої, соціальної, загальнонаукової, загальнокультурної, технологічної, комунікативної і комп'ютерної - визначається як одне з головних завдань сучасної школи України.

Відповідно до вимог нового Державного стандарту дошкільної, базової та повної загальної середньої освіти сучасна парадигма національної освіти в Україні грунтується на засадах особистісно зорієнтованого, компетентнісного і діяльнісного підходів, що реалізовані в освітніх галузях $\mathrm{i}$ відображені в результативних складових змісту дошкільної, базової і повної загальної середньої освіти. При цьому особистісно зорієнтований підхід до навчання забезпечує розвиток академічних, соціокультурних, соціально-психологічних та інших здібностей дошкільників та учнів, а компетентнісний підхід сприяє формуванню ключових і предметних компетентностей. Отже, в умовах модернізації змісту національної освіти в Україні, пошуку нових освітніх парадигм, орієнтованих на розвиток всебічно освіченої, творчої особистості, особливого значення набуває реалізація в педагогічній практиці сучасної школи саме компетентісного підходу.

Таким чином, сучасна освіта, зорієнтована на компетентісну модель, збільшує ії результативний компонент, визначає переміщення акцентів 3 накопичення обсягу знань на цілеспрямований розвиток ключових $\mathrm{i}$ предметних компетентностей як інтегрованої якості особистості.

Саме це завдання, постійно навчатися, бути творчим, інноваційним, працюючим над собою педагогом, ставлять викладачі перед собою та студентами.

3 цією метою викладачами ведеться грунтовна робота щодо підготовки матеріально-технічної та методичної бази для студентів ОКР «Молодший спеціаліст», «Бакалавр» $з$ фахових дисциплін, для підготовки та проведення уроків з інформатики.

Аналізуючи зміст своєї роботи ми можемо сказати, що для теоретично-практичної підготовки майбутніх вчителів намагаємось використовувати інноваційні технології (мультимедійні, мережеві), технології проблемного та інтерактивного навчання, робимо акцент на тому, що цікаво сучасному студенту, не відмовляючись від традиційної методики.

Не менш важливу роль у формуванні професійних компетентностей під час проходження практики, відіграють вдало підібрані практичні завдання, ситуативні задачі, ділові ігри, які використовуються під час вивчення фахових дисциплін, розв'язування яких вимагає від майбутніх вчителів активної практично-пошукової діяльності, самопідготовки та творчості.

Дослідивши структуру та зміст навчально-методичних, мультимедійних, програмно-технічних матеріалів педагогічної практики, пропонуємо найцікавіші приклади:

- навчально-методичний посібник для студентів-практикантів 3 додаткової кваліфікації «Вчитель інформатики в початковій школі», який розповсюджений в друкованому вигляді та на сайті електронної бібліотеки коледжу;

- електронні посібники, авторські сайти із зразками уроків для вчителя інформатики в початковій школі, матеріали для проведення виховних годин;

- систематизовано дидактичні матеріали для підготовки уроків інформатики на хмарному сервісі Padlet;

- підготовка і проведення засідань круглих столів, за участю студентів, вчителів шкіл області, викладачів, науковців, на яких обговорюються актуальні питання організації освітнього процесу, 3 метою набуття здатності ефективно діяти, розв'язуючи стандартні та проблемні методичні задачі;

- налагоджено спільне створення та використання конспектів, презентацій до уроків на сервісі Google Docs, інших хмарних сервісів;

- систематизовано та розповсюджено у вигляді веб-ресурсів на безкоштовному хостингу матеріали (технологічні картки, розробки уроків, пакети тестових завдань, фізкультхвилинки, відеозавдання ін.) для підготовки та проведення уроків інформатики.

Наскрізне застосування інформаційно-комунікаційних технологій в освітньому процесі стає пріоритетним інструментом забезпечення успіху нової української школи і перехід від одноразових проектів у системний процес, який охоплює всі види діяльності.

Інтегроване навчання легко і на сучасному етапі реалізується на уроках інформатики під час роботи над проектами, при поясненні нового матеріалу та на етапі закріплення. Студенти за 
допомогою сервісів, що вивчали під час методики навчання інформатики у коледжі, розробляють завдання з інших навчальних дисциплін, які учні виконують, наприклад, як завдання для розвитку навичок володіння клавіатурою, мишею.

Реалізація STEM-освіти може бути в якості предметів за вибором: наприклад, Робототехніка, «Цікава математика 3 Lego». Проте більшість фахівців схиляється до думки про STEM-освіта не як окремий центр при школі, а напрями, впроваджені у весь навчальний процес закладу, інтеграцією предметів. Адже конструювання можна використовувати не тільки для загального розвитку, а й у математиці, вивченні світу, розвиткові мови.

Використання конструкторів Lego, які дозволяють програмувати, зокрема комплекту WeDo 2.0 дозволяє проводити захоплюючу проектну діяльність з учнями 1-4 класів, використовуючи їх навички проектування, конструювання та програмування. Проекти, що входять до комплекту, наочно демонструють учням принципи роботи різних механізмів, фізичних законів або природних явищ.

На нашу думку, важливим для успішного формування професійних компетентностей в умовах професійно-практичної підготовки є залучення до створення професійно значущих продуктів. Тому i при вивченні інформативних дисциплін, і методики навчання інформатики ми ставимо акцент не на опануванні навичками користувача, а на підготовку до використання IT у професійній діяльності:

-розробка дидактичних матеріалів 3 використанням різних сервісів:Padlet, LearningApps, PowToon (створення навчальних відео) та Ted-Ed (створення відеороликів);

- формування вмінь розміщення навчальних матеріалів для своєї професійної діяльності на власному ресурсі (ведення власних блогів, створення та підтримка сайтів);

-використання смартфонів в якості цінних інструментів з навчальною метою, які підтримують знання, а не відволікають від навчального процесу;

-вміння будувати позитивну поведінку онлайн (як правильно використовувати соціальні медіа, як виробляти і публікувати цінний контент);

-вміння бути інноваційним (передбачає використання не тільки традиційних підручників, а й соціальних медіа, TED-роликів) та прагнути до саморозвитку (використовувати нові можливості, що дають сервіси дистанційного навчання, Prometheus, Coursera)

На заняттях 3 дисципліни «Методика навчання інформативної освітньої галузі» студенти знайомляться 3 новітнім освітнім програмним забезпеченням, принципами роботи інтерактивної панелі у лабораторії НУШ та смарткейсами для вчителя початкової школи та методикою іiі використання. У лабораторії НУШ студенти освоюють програму MozaBook.

Висновки і перспективи подальших досліджень: Таким чином, використавши методи наукових досліджень, проаналізувавши ряд літературних та інтернет-джерел, акумулювавши власний досвід та матеріали інших авторів, ми отримали наступні результати:

- обгрунтували окремі аспекти формування фахової компетентності вчителя початкової школи та вчителя інформатики в початковій школі;

- дослідили і описали структуру та зміст практичної підготовки майбутніх вчителів інформатики у початковій школі;

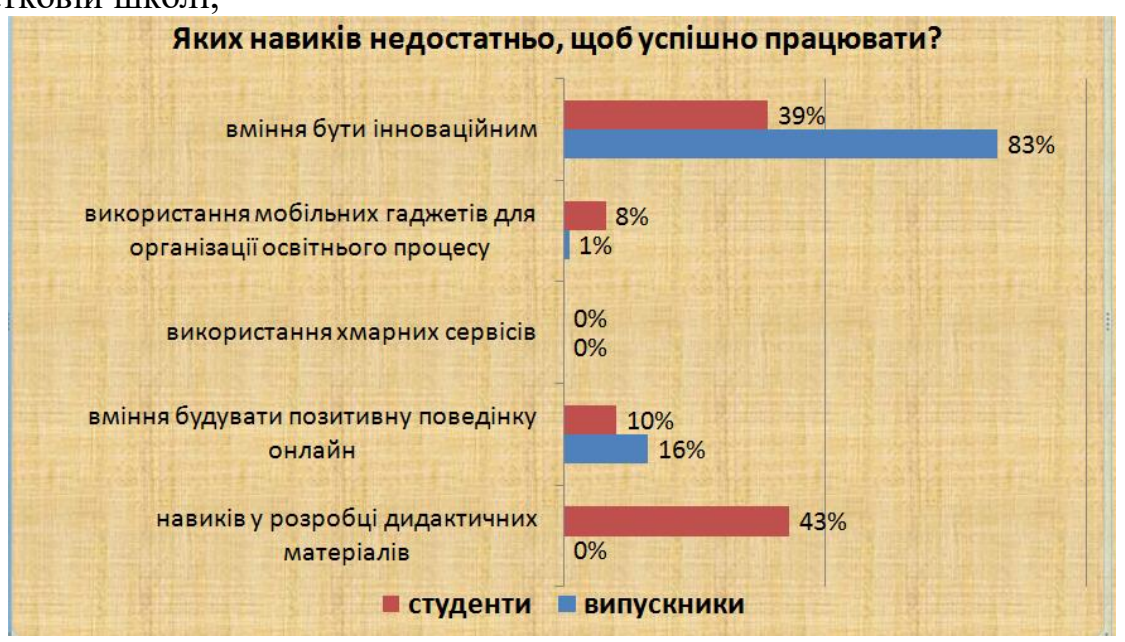

Рис. 2. Результати опитування студентів та випускників, з метою планування подальших досліджень

- переконались, що професійно-практична підготовка студентів коледжу - це пріоритетна система методів та засобів, спрямованих не тільки на набуття компетенцій шляхом отримання знань, 
їхнє запам'ятовування, а й на відтворення та творче застосування у процесі реальної педагогічної ситуації.

Надалі наші дослідження будуть спрямовані на вивчення окремих складових професійної компетентності майбутнього вчителя початкової школи, зокрема інформаційної компетентності 3 подальшою розробкою та використанням демонстраційних прикладів, інструктивних карток та інших навчально-методичних матеріалів.

1. Закон України «Про освіту».

\section{Список бібліографічного опису}

2. Національна доктрина розвитку освіти.

3. Онищенко I., Модель формування фахової компетентності майбутнього вчителя початкових класів [Електронний pecypc] / Ірина Онищенко - Режим доступу: http://archive.nbuv.gov.ua/portal

4. Пометун О. [Текст] Навчаємо по-іншому [посібник для викладачів професійно-технічних училищ] / О.Пометун та ін. К.,2008. - с. 14-15.

5. Психологія і педагогіка життєтворчості / Навч.-метод. посібник за ред. Л.В.Сохань, І.Г.Срмакова, В.О.Тихоновича. - K., 1996. $-792 \mathrm{c.}$

6. Симуляції або імітаційні ігри [Електронний ресурс] - Режим доступу: http://www.rusnauka.com

7. Ярошинська О. Формування фахової компетентності майбутніх учителів початкової школи в умовах освітнього середовища професійної підготовки [Електронний ресурс] / Олена Ярошинська - Режим доступу: http://irbis-nbuv.gov.ua

8. Ящук I. П. Формування життєвокомпетентної особистості : науково-методичний посібник / I. П. Ящук. Хмельницький : Видавництво Хмельницького гуманітарно-педагогічного інституту, 1999. - 54 с.

9. Технології опрацювання дискусійних питань, [Електронний ресурс] - Режим доступу: http://studopedia.com.ua/1_278032_tehnologii-opratsyuvannya-diskusiynih-pitan.html

\section{References}

1. The Law of Ukraine «On Education».

2. National doctrine of educational development.

3. Onishchenko, Model of formation of professional competence of the future elementary school teacher [Electronic resource] / Irina Onishchenko - Access mode: http://archive.nbuv.gov.ua/portal

4. Pometun O. [Text] We teach differently [a guide for teachers of vocational schools] / O.Pometun et al. $\neg \mathrm{K}$., 2008. - with. 14-15.

5. Psychology and pedagogy of life-creation / Educational method. manual ed. LVSokhan, IGYermakova, VO Tikhonovich. - K., 1996. - 792 p.

6. Simulations or Simulation Games [Online Resource] - Access Mode: http://www.rusnauka.com

7. Yaroshynska O. Formation of professional competence of future primary school teachers in the conditions of vocational training environment [Electronic resource] / Elena Yaroshynska - Access mode: http://irbis-nbuv.gov.ua

8. Yashchuk IP Formation of a life-competent personality: a scientific and methodological manual / IP Yashchuk. Khmelnitsky: Publishing House of Khmelnytsky Humanitarian and Pedagogical Institute, 1999. - 54 p.

9. Technologies for working out discussion questions, [Electronic resource] - Access mode: http://studopedia.com.ua/1_278032_tehnologii-opratsyuvannya-diskusiynih-pitan.html

Рецензенти: Муляр Вадим Петрович, кандидат педагогічних наук, доцент кафедри експериментальної фізики та інформаційно-вимірювальних технологій Східноєвропейського національного університету ім. Лесі Українки, Лук'янчук Мар'яна Василівна, кандидат педагогічних наук, викладач іноземних мов Луцького педагогічного коледжу

Стаття надійшла 03.04.2020 